\title{
A rare case of giant verruciform xanthoma in the palate
}

\author{
Relato de caso raro de extenso xantoma verruciforme no palato
}

Eduardo Augusto ROSA'

Rivadávio Fernandes Batista de AMORIM²

\begin{abstract}
Verruciform xanthoma represents a rare disease of unknown etiology that typically affects the oral mucosa. In most cases, it is asymptomatic and characterized by a well demarcated elevation with irregular or papillary surface. The gums are the most affected oral site, and the lesion is usually less than $2 \mathrm{~cm}$ in diameter. The aim of this study is to report a rare case of an extensive verruciform xanthoma in the hard palate and gums of a 55-year-old male. Clinically, the well delimitated, reddish, elastic lesion measuring approximately $2.8 \times 1.5 \mathrm{~cm}$ had a slightly granular surface. Histopathological analysis found proliferative epithelial activity with evident papillomatosis, parakeratosis, and large epithelial ridges. Xanthomatous cells with clear, vacuolated cytoplasm were detected in the lamina propria. The patient has been disease free for 18 months. According to an extensive research in the PubMed, MEDLINE, and Lilacs databases, this paper describes one of the most extensive cases of verruciform xanthoma reported in the literature.
\end{abstract}

Indexing terms: Mouth mucosa. Palate. Pathology, oral. Xanthomatosis.

\section{RESUMO}

O xantoma verruciforme é uma lesão rara de etiologia não determinada, que acomete, principalmente, a mucosa oral. Na maioria das vezes é assintomática, caracterizando-se por uma elevação bem-delimitada, de superfície rugosa ou papilar, e sua principal localização na boca é a gengiva. Com relação ao tamanho, a maioria das lesões não ultrapassa $2 \mathrm{~cm}$ no seu maior diâmetro. O objetivo do presente trabalho é relatar um caso raro de extenso xantoma verruciforme em paciente do gênero masculino, de 55 anos, apresentando lesão localizada no palato duro e na gengiva palatina. Clinicamente, a lesão possuía bordas bem-destacadas, de superfície levemente granular e coloração avermelhada, com consistência elástica, medindo aproximadamente $2,8 \times 1,5 \mathrm{~cm}$. O exame histopatológico demonstrou a presença de proliferação do epitélio de revestimento, exibindo papilomatose, paraceratose e alongamento das cristas epiteliais. Na lâmina própria, células xantomatosas com citoplasma claro e vacuolado puderam ser observadas. O paciente encontra-se livre de recidivas após 18 meses de acompanhamento clínico. De acordo com extensa pesquisa em bases de dados (pubmed, medline, lilacs), o presente caso representa uma das maiores lesões do tipo xantoma verruciforme já relatadas na literatura.

Termos de indexação: Mucosa bucal. Palato. Patologia bucal. Xantomatose.

\section{INTRODUCTION}

Verruciform xanthoma is a rare benign lesion first reported by Shafer ${ }^{1}$ in 1971. It manifests mainly in the oral mucosa, but cases of verruciform xanthoma in the vulva, scrotum, penis, anal region, and extremities have been described ${ }^{2-3}$. The lesion is usually solitary and asymptomatic, and can have been present from a few weeks to years ${ }^{4}$. Sopena et al. ${ }^{5}$ described a case of disseminated verruciform xanthoma involving the hands, feet, genital region, ears, and palate. From the clinical point of view, verruciform xanthoma is characterized by a well delimited rough or papillary elevation and may be depressed or ulcerated at the center ${ }^{4,6-7}$. Its color varies from pink, red, yellow, or brownish, to whitish or grey ${ }^{4}$.

Oral verruciform xanthoma is usually found on the gums ${ }^{4,8}$. The mean ages of affected individuals vary from 45 to 58.3 years $^{8-9}$. Verruciform xanthoma may be associated with other conditions, such as lichen planus, lupus, and squamous cell carcinoma $a^{2,10-12}$.

Histologically, verruciform xanthoma is characterized by a proliferation of the surface epithelium, exhibiting papillomatosis, parakeratosis, and elongation of

\footnotetext{
${ }^{1}$ Universidade Católica de Brasília, Faculdade de Odontologia. QS 7 lote 1, Águas Claras, 71966-100, Brasília, DF, Brasil. Correspondência para / Correspondence to: EA ROSA.E-mail: <eduardorosa@yahoo.com.br>.

${ }^{2}$ Universidade de Brasília, Faculdade de Medicina, Departamento de Patologia. Brasília, DF, Brasil.
} 
of the rete ridges. Xanthomatous cells in the lamina propria may have a clear and vacuolated cytoplasm. Three architectural patterns were proposed by Nowparast et al. ${ }^{13}$ in 1981: verrucous, papillary, and flat. The verrucous type presents acanthosis, hyperparakeratosis, and elongation of the rete ridges; the papillary type presents numerous finger-like projections containing connective tissue and parakeratin crypts; and the flat type presents subsurface epithelial proliferation ${ }^{8-9}$. Immunohistochemical studies show that xanthomatous cells are positive for CD68+, so they are considered cells of the macrophage lineage $e^{4,6,14}$

\section{CASE REPORT}

A 55-year-old Brown male visited the oralmaxillofacial service because of a lesion located in the hard palate and palatal gingiva extending from the distal side of the canine to the distal side of the second molar, approaching the palatine raphe. The affected teeth were abraded, and the patient presented advanced periodontal disease with gingival recession and exposure of the palatine roots. The lesion had well delimited borders, which were slightly more elevated than the central portion. The surface was marginally granular, elastic, and reddish, measuring approximately $2.8 \times 1.5 \mathrm{~cm}$ (Figure 1). Cervical lymph nodes were not palpable. The patient had noticed the lesion approximately one month before the visit and did not report pain, drainage of secretion or blood, significant systemic changes, or any other important change. The clinical picture called for an incisional biopsy and a histopathological examination. The histological cuts stained with hematoxylin-eosin (HE) were lined with a stratified, parakeratinized pavement epithelium. There was abundant formation of parakeratin in many fields. Additionally, the epithelium presented papillomatosis, acanthosis, and elongated projections of the ridges toward the lamina propria (Figures 2 and 3). Some crypts containing parakeratin could also be observed on the epithelial surface (Figure 4). Cells with a clear and foamy cytoplasm and an ovoid nucleus close to their center were present between the epithelial crypts, embedded in the papillae of the connective tissue (Figures 5 and 6 ). Their size diversity and the association of the cytological aspects of the clear cells indicated that they were xanthomatous cells. The set of histopathological evidences led to the diagnosis of verruciform xanthoma. The lesion was completely excised and the excisional biopsy findings corroborated the histological aspects found previously by the incisional biopsy. The patient has been recurrence free for 18 months now. The patient was informed about the nature of the lesion and the need of follow-up. He also read and signed an informed consent form for the performance and publication of scientific studies.

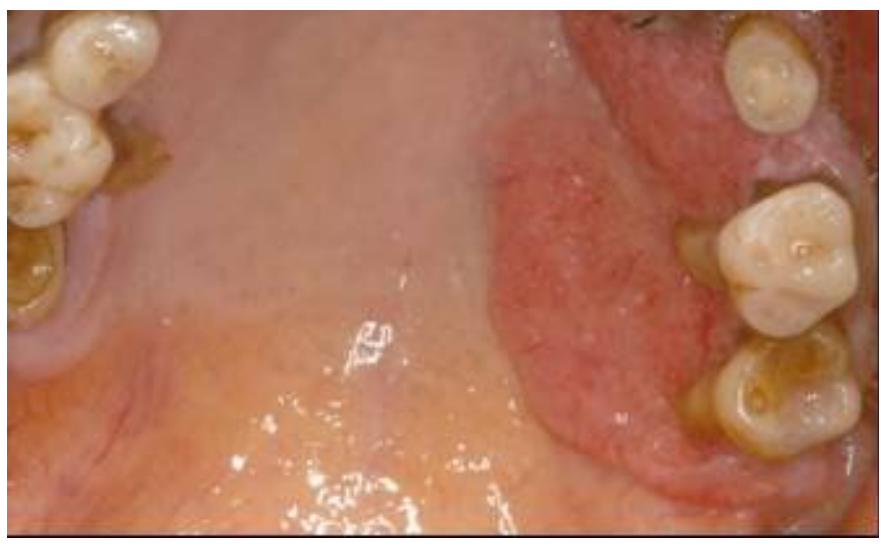

Figure 1. Clinical aspect of the lesion, showing the involvement of the palatine mucosa and gum.

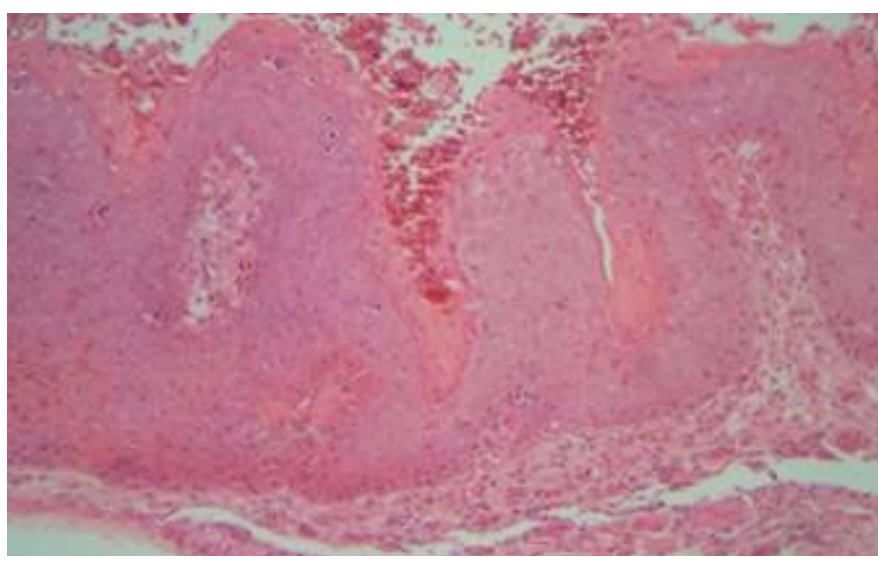

Figure 2. Histological cut showing the stratified pavement epithelium with papillomatosis, parakeratosis, and elongated rete ridges (Hematoxylineosin 100x)

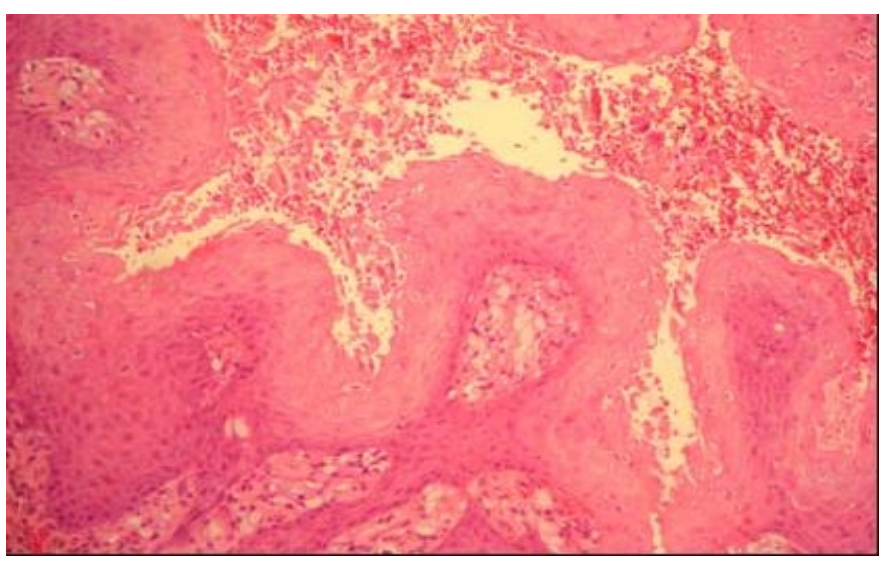

Figure 3. Histological cut showing xanthomatous cells between the epithelial papillomatous projections (Hematoxylin-eosin 100x). 


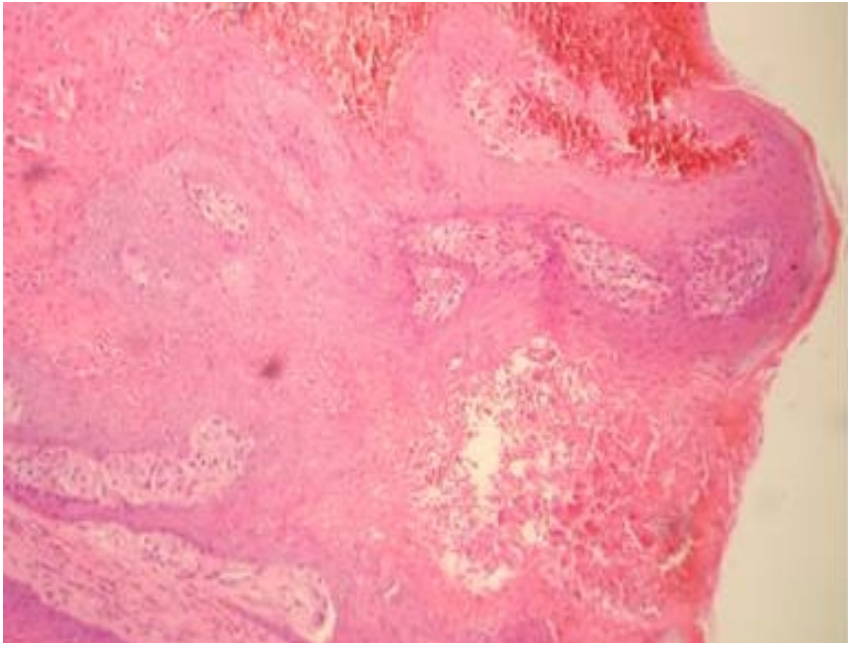

Figure 4. Histological cut highlighting a rete ridge filled with keratin (Hematoxylineosin 100X)

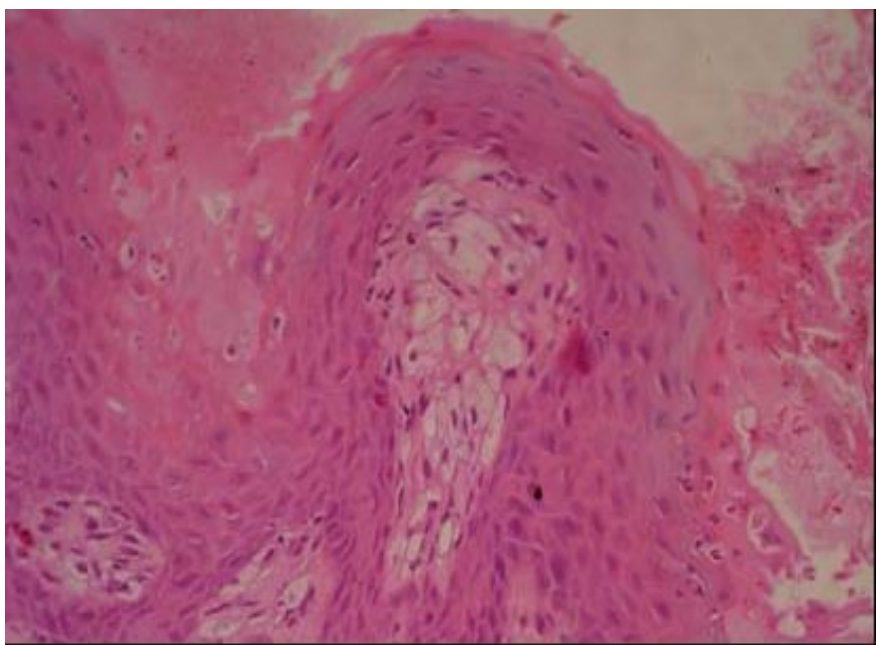

Figure 5. Histological cut showing cells in the xanthomatous connective tissue close to the epithelium (Hematoxylin-eosin 400x).

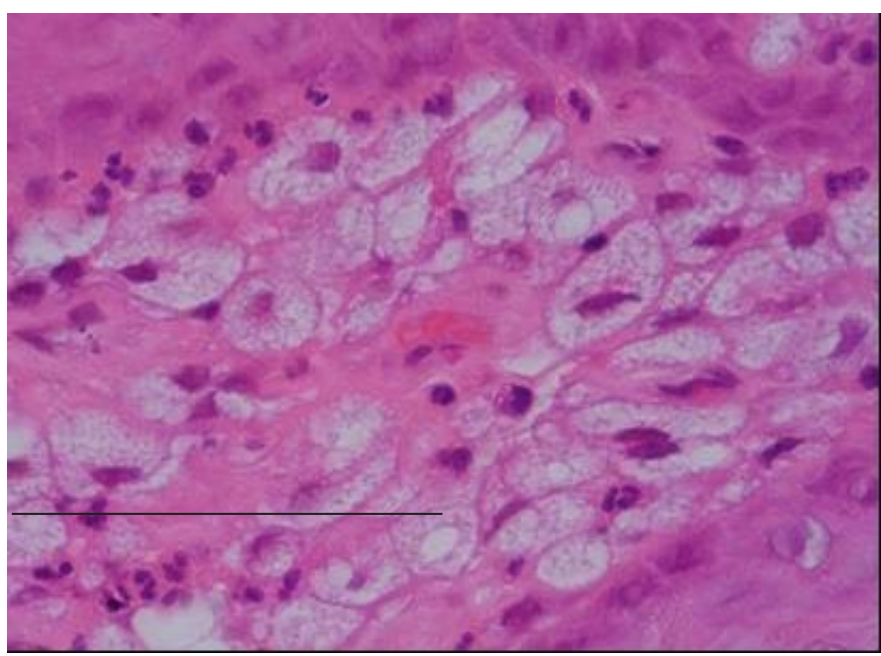

Figure 6. Detail of the xanthomatous cells with clear vacuolated cytoplasm and ovoid nucleus. Neutrophils and fibroblasts are also visible. (Hematoxylin-eosin 1000X)

\section{DISCUSSION}

Oral verruciform xanthoma occurs very infrequently. Up to 2001, only 282 cases had been reported4. Since 2001, the following reports written in English were found in PubMed: a series with 15 new cases described by $\mathrm{Yu}$ et al. ${ }^{8}$; another two cases reported by Sah et al.7; and 11 isolated case reports, totaling 29 new cases including the present case $\mathrm{e}^{5,11-12,15-22}$. Among all cited studies, only five verruciform xanthomas were described, in addition to the present case ${ }^{12,14}$. More cases have been described involving Asians; Philipsen et al.4 found 109 verruciform xanthomas in Japanese in their series of 282 cases, and another 15 cases were described in Taiwan more recently ${ }^{8}$.

Changes in the lipid metabolism and viruses do not seem to induce verruciform xanthoma ${ }^{7,9}$. Oliveira et al. ${ }^{14}$ suggest the development of an immune response, similar to that associated with lichen planus. Meanwhile, Ide et al. ${ }^{9}$ speculated that verruciform xanthoma has a multifactorial etiology, including periodontal pathogens, mechanical stimulation, tobacco, alcohol, and dietary allergens or sensitizing agents, among others.

The case reported herein involved the gum and palate, which consist of masticatory mucosa. Philipsen et al. ${ }^{4}$ reported that the gum is the commonest site for verruciform xanthoma, followed by the palate in the 173 non-Japanese patients they studied, and 17 of these cases involved both the palate and the gum. Isolated palate involvement was also less frequent in the retrospective study of 16 cases conducted by Rawal et al. ${ }^{6}$, who found only three palatine lesions. In a series of 15 cases, Yu et al. ${ }^{8}$ did not find any verruciform xanthoma in the palate but found one lesion in the palatine gingiva. Sopena et al.5 found small lesions in the palate of a patient with many verruciform xanthomas in the skin.

In the 15 cases reported by $Y u$ et al. ${ }^{8}$, the mean length of the verruciform xanthomas was $0.8 \mathrm{~cm}$. Only two lesions had a length greater than one centimeter, and the biggest lesion measured $2.0 \times 1.0 \mathrm{~cm}$. The four lesions reported by Oliveira et al. ${ }^{14}$ varied from 0.4 to $2.0 \mathrm{~cm}$. Skin verruciform xanthomas can be much larger: a case affecting more than $15 \mathrm{~cm}$ of skin has already been reported ${ }^{3}$. The lesion described herein measured roughly $2.8 \times 1.5 \mathrm{~cm}$. Of all the studies reviewed for this manuscript, the present lesion was the largest oral lesion.

The clinical characteristics of verruciform xanthoma are not specific. The differential diagnosis includes squamous cell papilloma, wart, verrucous hyperplasia, and verrucous carcinoma ${ }^{8,17,23}$. Only three of the 15 cases reported by Yu et al. ${ }^{8}$ were hypothesized to 
to be verruciform xanthomas, which may be attributed to their rarity in dental practice. Other hypotheses included five verrucous hyperplasias and two papillomas. Biopsy is a must because verruciform xanthoma diagnosis depends on the presence of xanthomatous cells since these cells are not present in the other conditions listed in the differential diagnosis $4,8,17,23$. Moreover, verrucous carcinoma is distinguished by the presence of cellular atypia, while papilloma and warts are distinguished by signs of viral induction ${ }^{17}$.

\section{CONCLUSION}

The present article reports a new case of a very extensive verruciform xanthoma involving the palate and palatal gingiva. Contrary to most of the lesions described

\section{REFERENCES}

1. Shafer WG. Verruciform xanthoma. Oral Surg Oral Med Oral Pathol. 1971;31:784-9.

2. Mannes KD, Dekle $C L$, Requena L, Sangueza OP. Verruciform xanthoma associated with squamous cell carcinoma. Am J Dermopathol. 1999;21(1):66-9.

3. Agarwal-Antal N, Zimmermann J, Scholz T, Noyes RD, Leachman SA. A giant verruciform xanthoma. J Cutan Pathol. 2002;29(2):119-24. doi: 10.1034/j.1600-0560.2002.290210.x.

4. Philipsen HP, Reichart PA, Takata T, Ogawa I. Verruciform xanthoma: biological profile of 282 oral lesions based on a literature survey with nine new cases from Japan. Oral Oncol. 2003;39(4):325-36. doi: 10.1016/S1368-8375(02)00088-X.

5. Sopena J, Gamo R, Iglesias L, Rodriguez-Peralto JL. Disseminated verruciform xanthoma. Br J Dermatol. 2004;151(3):717-9. doi: 10.1111/j.1365-2133.2004.06164.x.

6. Rawal SY, Kalmar JR, Tatakis DN. Verruciform xanthoma: immunohistochemical charecterization of xanthoma cell phenotypes. J Periodontol. 2007;78(3):504-9. doi:10.1902/ jop.2007.060196.

7. Sah K, Kale AD, Hallikirimath S. Verruciform xanthoma: report of two cases and review on pathogenesis. J Oral Maxillofac Pathol. 2008;12(1):41-4.

8. Yu CH, Tsai TC, Wang JT, Liu BY, Wang YP, Sun A, et al. Oral verruciform Xanthoma: a clinicopathologic study of 15 cases. J Formos Med Assoc. 2007;106(2):141-7. doi: 10.1016/S09296646(09)60230-8. in the literature, the study lesion shows that verruciform xanthomas can reach significant proportions in certain situations, but the reasons for the more aggressive phenotype of these cases are not yet understood.

\section{Collaborators}

EA ROSA reviewed the literature, conceived and wrote the manuscript, and was co-responsible for the histopathological diagnosis of the study case. RFB AMORIM wrote the abstract, analyzed the text, reviewed the last version of the manuscript, and was co-responsible for the histopathological diagnosis of the study case.

9. Ide F, Obara K, Yamada H, Mishima K, Saito I, Kusama K. Cellular basis of verruciform xanthoma: immunohistochemical and ultrastructural characterization. Oral Dis. 2008;14(2):150-7. doi: 10.1111/j.1601-0825.2007.01362.x.

10. Polonowita $A D$, Firth $N A$, Rich $A M$. Verruciform xanthoma and concomitant lichen planus of the oral mucosa. Int J Oral Maxillofac Surg. 1999;28(1):62-6.

11. Poulopoulos AK, Epivatianos A, Zaraboukas T, Antoniades D. Verruciform xanthoma coexisting with oral discoid lupus eritematosus. Br J Oral Maxillofaciac Surg. 2007;45(2):159-60. doi: 10.1016/j.bjoms.2005.06.020.

12. Abinder $A L$, de Souza Quirino $M R$, Brandão $A A$. Verruciform xanthoma and neurofibromatosis: a case report. $\mathrm{Br} J$ Oral Maxillofaciac Surg. 2010;49(4):e6-7. doi: 10.1016/j. bjoms.2010.06.013.

13. Nowparast B, Howell FV, Rick GM. Verruciform xanthoma: a clinicopathologic review and report of fifty-four cases. Oral Surg. 1981;51(6):619-25. doi: 10.1016/S0030-4220(81)80012-6.

14. Oliveira PT, Jaeger RG, Cabral LA, Carvalho YR, Costa AL, Jaeger MM. Verruciform xanthoma of the oral mucosa. Report of four cases and a review of the literature. Oral Oncol. 2001;37(3):32631. doi: 10.1016/\$1368-8375(00)00068-3.

15. Kim JY, Jung HD, Choe YS, Lee WJ, Lee SJ, Kim do W, et al. A Case of Xanthoma Disseminatum Accentuating over the Eyelids. Ann Dermatol. 2010;22(3):353-7. doi: 10.5021/ad.2010.22.3.353.

16. Cheng YS, Wright J, Lucente J, McQuade MJ. Oral and maxillofacial pathology case of the month: verruciform xanthoma. Tex Dent J. 2010;127(1):126-7.

17. Mete $\mathrm{O}$, Kurklu E, Bilgic B, Beka H, Unur M. Flat-type verruciform xanthoma of the tongue and its differential diagnosis. Dermatol Online J. 2009;15(9):5. 
18. Sharma D, Pradeep AR. Xanthomatous changes in case provisionally diagnosed as fibroma: a case report. N Y State Dent J. $2007 ; 73(5): 61-3$.

19. Visintini E, Rizzardi C, Chiandussi S, Biasotto M, Melato M, Di Lenarda R. Verruciform xanthoma of the oral mucosa. Report of a case. Minerva Stomatol. 2006;55(11-12):639-45. doi: $10.1155 / 2013 / 528967$.

20. Pradhan S. Verruciform xanthoma of the oral mucosa. JNMA J Nepal Med Assoc 2006;45(161):207-11.

21. Mansour M, Kessler HP. Oral and maxillofacial pathology case of the month. Verruciform xanthoma. Tex Dent J. 2005;122(12):1248-9, 1252-3.
22. Damm DD, Fantasia JE. Rough white patch of gingiva. Verruciform xanthoma. Gen Dent. 2002;50(4):378, 80.

23. Klieb HBE, Raphael SJ. Comparative study of the expression of p53, Ki67, E-cadherin and MMP1 in verrucous hyperplasia and verrucous carcinoma of the oral cavity. Head and Neck Pathol. 2007:1(2):118-22

Received on: 17/10/2011

Final version resubmitted on: 15/2/2012

Approved on: 19/3/2012 
